Democracy in Retreat 
This page intentionally left blank 


\title{
Democracy in Retreat
}

The Revolt of the Middle Class and the Worldwide Decline of Representative Government

\section{Joshua Kurlantzick}

\author{
Yale UnIVERSITy PRESS \\ New Haven \& London
}




\section{Copyright @ 2013 by Joshua Kurlantzick.}

All rights reserved.

This book may not be reproduced, in whole or in part, including illustrations, in any form (beyond that copying permitted by Sections 107 and 108 of the U.S. Copyright Law and except by reviewers for the public press), without written permission from the publishers.

Yale University Press books may be purchased in quantity for educational, business, or promotional use. For information, please e-mail sales.press@yale.edu (U.S. office) or sales@ yaleup.co.uk (U.K. office).

Set in Granjon type by Westchester Book Group, Danbury, Connecticut.

Printed in the United States of America.

\section{Library of Congress Cataloging-in-Publication Data}

Kurlantzick, Joshua, 1976-

Democracy in retreat : the revolt of the middle class and the worldwide decline of representative government / Joshua Kurlantzick.

p. $\quad \mathrm{cm}$.

Includes bibliographical references and index.

ISBN 978-0-300-17538-7 (alk. paper)

1. Democracy-Case studies. 2. Democratization-Case studies. I. Title. JC423.K857 2013

$321.8-\mathrm{dc} 23$

2012031764

A catalogue record for this book is available from the British Library.

This paper meets the requirements of ANSI/NISO Z39.48-1992 (Permanence of Paper). 
THE COUNCIL ON FOREIGN RELATIONS

The Council on Foreign Relations (CFR) is an independent, nonpartisan membership organization, think tank, and publisher dedicated to being a resource for its members, government officials, business executives, journalists, educators and students, civic and religious leaders, and other interested citizens in order to help them better understand the world and the foreign policy choices facing the United States and other countries. Founded in 1921, CFR carries out its mission by maintaining a diverse membership, with special programs to promote interest and develop expertise in the next generation of foreign policy leaders; convening meetings at its headquarters in New York and in Washington, DC, and other cities where senior government officials, members of Congress, global leaders, and prominent thinkers come together with CFR members to discuss and debate major international issues; supporting a Studies Program that fosters independent research, enabling CFR scholars to produce articles, reports, and books and hold roundtables that analyze foreign policy issues and make concrete policy recommendations; publishing Foreign Affairs, the preeminent journal on international affairs and U.S. foreign policy; sponsoring Independent Task Forces that produce reports with both findings and policy prescriptions on the most important foreign policy topics; and providing up-to-date information and analysis about world events and American foreign policy on its website, www.cfr.org.

THE COUNCIL ON FOREIGN RELATIONS TAKES NO INSTITUTIONAL POSITION ON POLICY ISSUES AND HAS NO AFFILIATION WITH THE U.S. GOVERNMENT. ALL STATEMENTS OF FACT AND EXPRESSIONS OF OPINION CONTAINED IN ITS PUBLICATIONS ARE THE SOLE RESPONSIBILITY OF THE AUTHOR OR AUTHORS. 
This page intentionally left blank 
For Shira 
This page intentionally left blank 